\title{
Appearance of oak lace bug (Corythucha arcuata Say, 1832) on sweet chestnut in Hungary (Heteroptera: Tingidae)
}

\author{
Gabriella Enikő Kovács*, Antal Nagy, László Radócz, István Szarukán
}

Plant Protection Institute, University of Debrecen,

H-4032 Debrecen, Böszörményi str. 138., Hungary

\begin{abstract}
Kovács, G.E., Nagy, A., Radócz, L., Szarukán, I., 2020. Appearance of oak lace bug (Corythucha arcuata Say, 1832) on sweet chestnut in Hungary (Heteroptera: Tingidae). Folia Oecologica, 47 (2): 140143.

Oak lace bug (Corythucha arcuata) has caused increasing damage throughout Europe since its appearance in 2000. In Hungary, it has become a dangerous pest of Quercus species in recent years. They frequently appear on ornamental and fruit trees, either, but this type of damage is not significant. Castanea species are known as their common host plants in their native area, but in Europe, it was detected only in Bulgaria. In this paper, we provide the first record of oak lace bug on sweet chestnut (C. sativa) in Hungary, which represents only the second European data on Castanea species. The pest was found in Debrecen, East Hungary.
\end{abstract}

\section{Keywords}

Castanea sativa, host plant, infestation, oak lace bug

\section{Introduction}

Oak lace bug (OLB, Corythucha arcuata) is native in the Nearctic region, and originally distributed in the United States and South Canada (Drake and Ruhoff, 1965). C. arcuata was found in two European regions at the same time. One of them was North Italy (Piedmont and Lombardy), where the first populations were found in 2000 (BERNARDINELLI, 2000), and the other observation took place in Northwest Turkey, where it was detected in 2002 (Mutun, 2003). At the beginning of 2000's, OLB was widely distributed in Italy, suggesting earlier introduction (BERNARDINELLI and ZANDIGIACOMO, 2000). The first Hungarian populations came probably from the Turkish source area at the beginning of the 2010's (CsóKA et al., 2013). It was found in Croatia at the same time (HrAšoveC et al., 2013). OLB has two or three generations annually (CsóKA and Hirka, 2017.). Due to their rapid reproduction and spread, the pest was appeared in Slovakia shortly af- ter the emergence, rapid spread and massive infestation in Hungary (CSEPELÉNYI et al., 2017; ZUBRIK et al., 2019). Its expansion was not monitored in each country through the expansion routes, thus e.g. in Romania it was detected only after the Hungarian observation in 2015 (Don et al., 2016; Chireceanu et al., 2017) (Fig. 1).

Lace bugs generally spread passively on anemo and anthropochorous ways, since they generally do not fly well (RABITSCH, 2008). Eggs and larvae hide in the foliage, while adults usually lurk in bark cracks. During forestation, it can be introduced from distant sources by saplings or even with timber of their host plants (KUCUKBASMACI, 2014).

According to the review of their European status (CsóKA et al., 2020), the pest feeds on trees belonging to the Fagaceae family, especially on 48 different Quercus species. Their secondary occurrence can be observed on Castanea and Fagus tree species and some members of Rosaceae and Betulaceae plant families. Their appearance

*Corresponding author: e-mail: kovacs.gabriella@agr.unideb.hu 
on sweet chestnut (Castanea sativa) has been studied in eight countries, but it has been proved only in Bulgaria (Simov et al., 2018) so far.

\section{Materials and methods}

C. arcuata was unexpectedly found on sweet chestnuts in the suburb of Debrecen (East Hungary) on 28th September 2019. The sampling site was a garden with only two sweet chestnut trees (GPS: $47^{\circ} 22.7^{\prime} \mathrm{N}$; 20 $0^{\circ} 54.2^{\prime} \mathrm{E}$ ). The sweet chestnut is not common in this area, where fruit trees (apple, pear, apricot, plum, cherry, and sour cherry) and evergreen ornamental plants (e.g. Pinus spp., Juniperus spp. and Thuja spp.) are typical. The garden was surrounded by a forest strip (with pine and poplar) and other extensive orchards. In the surroundings there was a large natural forest area of Debrecen-Hajdúböszörmény oak staff Natura 2000 site (HUHN20033).

The caught specimens of OLB were determined according to the keys of Dobreva et al. (2013) and Golub and Soboleva (2018): since lace bugs (e.g., C. arcuata, $C$. ciliata, $S$. pyri) are similar regarding the size (2.8 to 3.2 $\mathrm{mm}$ ), the identification should be based on the pattern and morphology of their wings and paranotum. The pattern of forewings of $C$. arcuata and S. pyri is similar, but the shape of the wings and the edge of the paranotum are different. The wing of $S$. pyri is rounded at the front and the paranotum has a smooth border (Fig. 2c). The wing of $C$. arcuata is angular at the front and elongated spines are at the edge of its paranotum (Fig. 2b). Wings and paranotum of $C$. arcuata and $C$. ciliata are similar, but there is difference in their colour (Fig. 2a and 2b).
The abundance of the pest was estimated by the ratio of the damaged leaves, and their mean density on leaves (individual/leaf). Density was calculated based on 20 sampled leaves.

\section{Results and discussion}

The presence and damage caused by $C$. arcuata on sweet chestnut was detected firstly in East Hungary in the suburb of Debrecen (GPS: $47^{\circ} 22.7^{\prime} \mathrm{N}$; $\left.20^{\circ} 54.2^{\prime} \mathrm{E}\right)$ on 28 th September 2019, where was no other appropriate Fagaceae host plant in the neighbourhood.

On damaged sweet chestnuts, typical symptoms were observed: leaves became faded and withered and individuals in different phenological stages were detected at both sides of leaves (Fig. 3). The estimated ratio of the damaged leaves was nearly $100 \%$. The mean number of nymphs was 15 , while the mean number of imagos was 5 individuals/ leaf. Also numerous eggs were observed in each sampled leaf. The high abundance of the pest on these two isolated trees of secondary host shows strong infestation of the area and draws attention to the need for investigation and even protection of close natural oak forests belonging to the N2000 network.

Sweet chestnut has economic importance especially in Italy, Spain, and Portugal but in these countries damage of this pest has not been observed in orchards yet. Considering our results, damage of OLB on sweet chestnut are known only in Bulgaria (Simov et al., 2018) and in Hungary. The risk of infestation of Mediterranean sweet chestnut orchards will likely increase due to the extent of the area and the increase in the abundance of $C$. arcuata in the future.

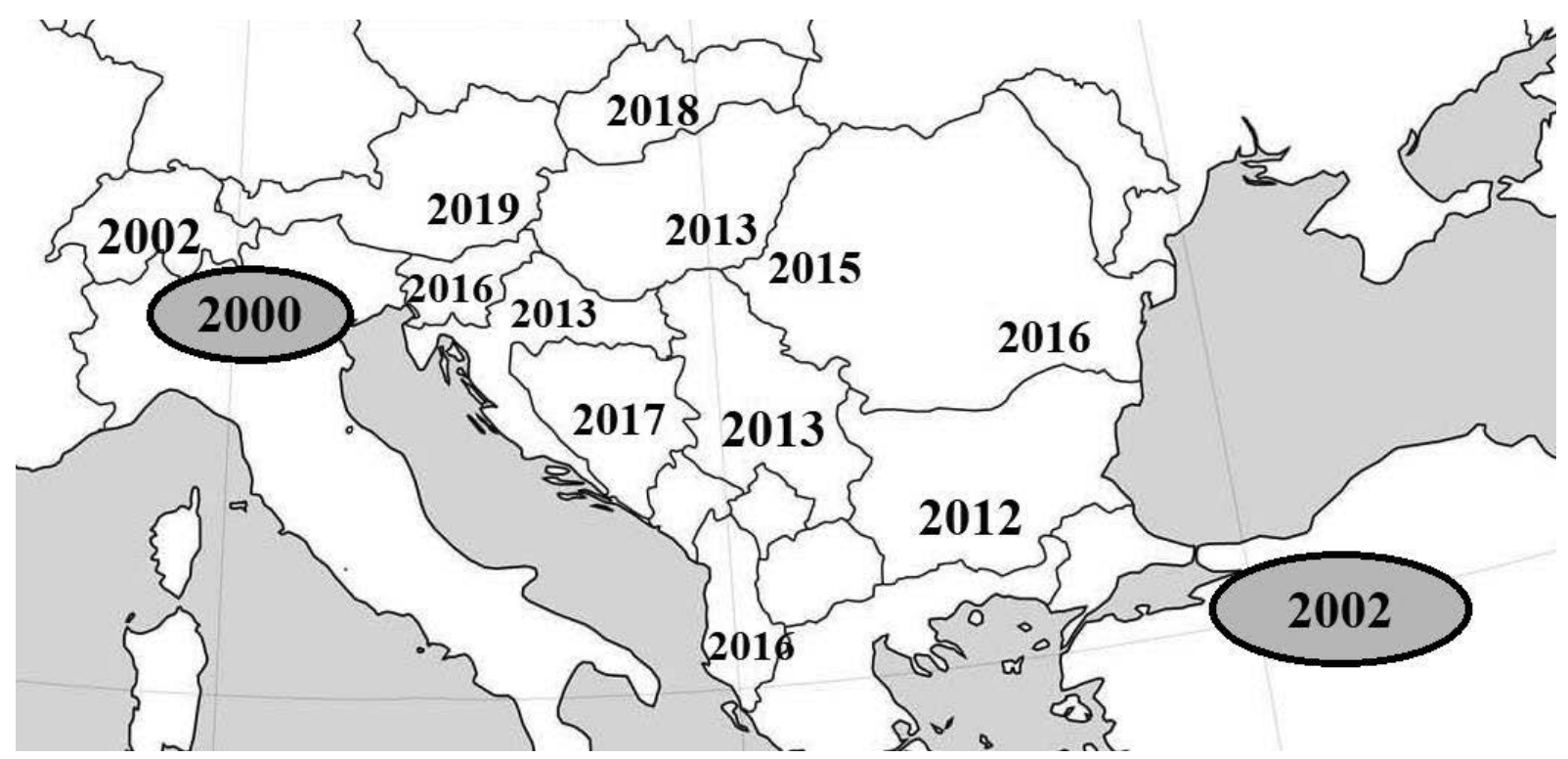

Fig. 1. Distribution of oak lace bug (Corythucha arcuata) in Southeast Europe with the year of their first record from a given country (CsóKA et al., 2020). Grey areas represent source areas of the European spread. Authors' own elaboration. 

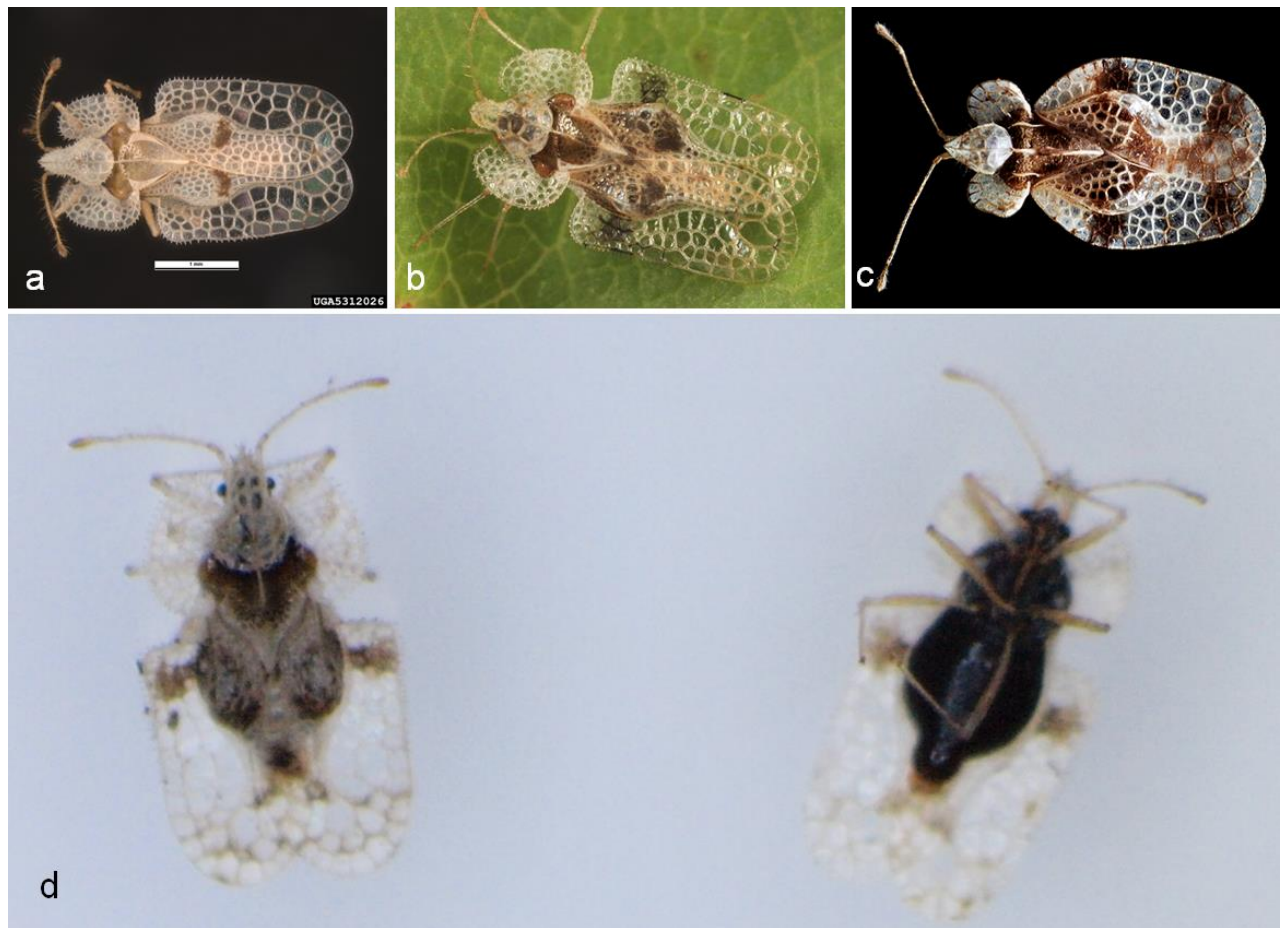

Fig. 2. Morphologically similar lace bug species lives in Hungary. (a) Corythucha ciliata (Pest AND Diseases Image LiBRARY, 2007); (b) Corythucha arcuata (MurRaY, 2008); (c) Stephanitis pyri (DAVID'YAN and NeYMORovets, 2004); (d) stereomicroscopic image of C. arcuata imagos sampled in Debrecen Hungary (photo by G. Kovács).

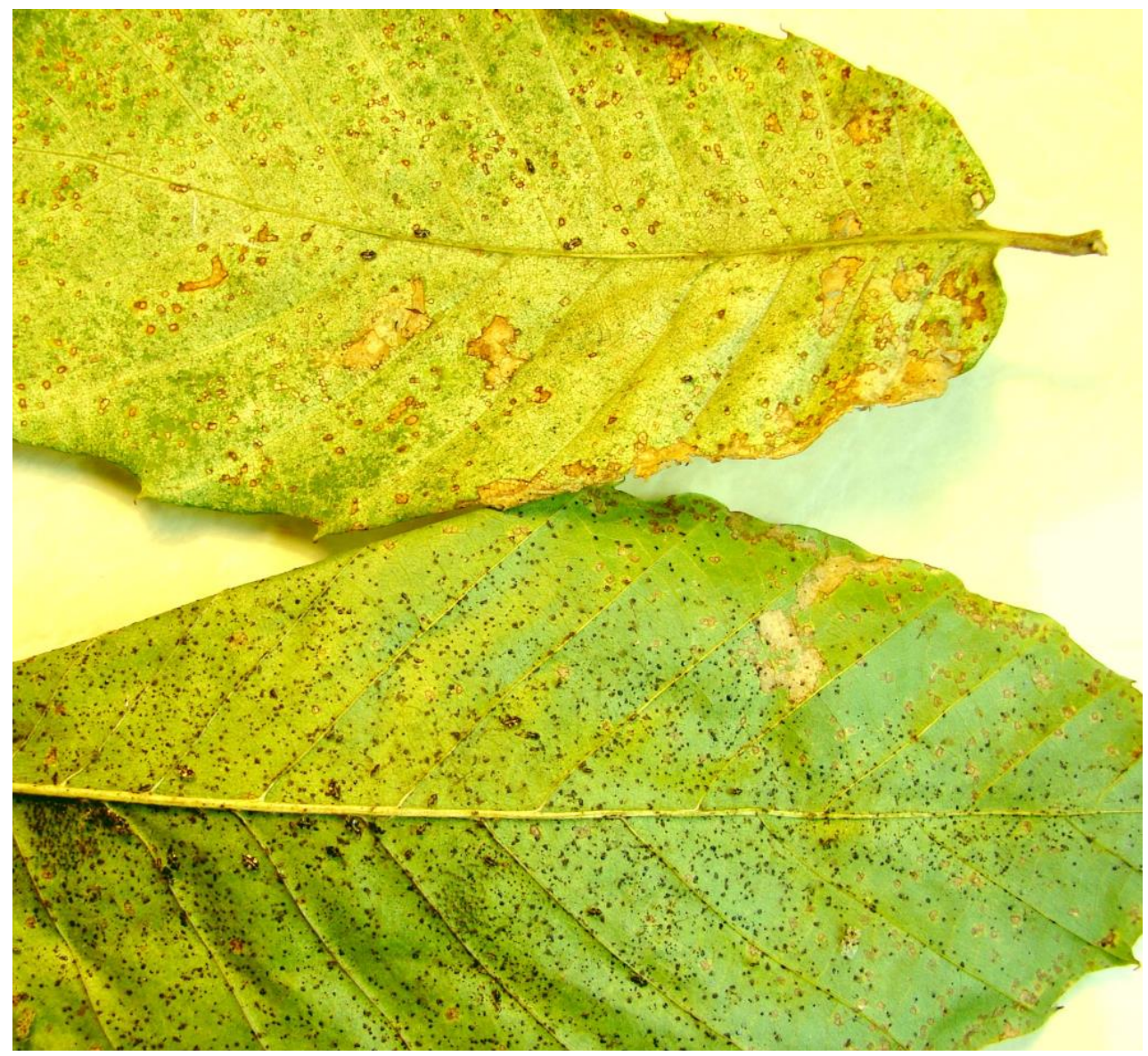

Fig. 3. Damaged sweet chestnut leaves with nymphs and imagos on it. Photo by authors. 


\section{Acknowledgement}

The research was financed by the Higher Education Institutional Excellence Programme (NKFIH-1150-6/2019) of the Ministry of Innovation and Technology in Hungary, within the framework of the 4 th thematic programme of the University of Debrecen.

\section{References}

Bernardinelli, I., 2000. Distribution of the oak lace bug Corythucha arcuata (Say) in Northern Italy (Heteroptera: Tingidae). Redia, 83: 157-162.

Bernardinelli, I., Zandigiacomo, P., 2000. Prima segnalazione di Corythucha arcuata (Say) (Heteroptera, Tingidae) in Europa [First report of Corythucha arcuata (Say) (Heteroptera, Tingidae) in Europe]. Informatore Fitopatologico, 12: 47-49.

Chireceanu, C., Teodoru, A., Chirilonie, A., 2017. New records of the oak lace bug Corythucha arcuata (Say, 1832) (Hemiptera: Tingidae) in Southern Romania. Acta Zoologica Bulgarica, Suppl. 9: 297-299.

Csepelényi, M., Hirka, A., SzÉnÁsi, Á., Mikó, Á., SzŐCs, L., CsóKA, G., 2017. Az inváziós Tölgy csipkéspoloska [Corythucha arcuata (Say, 1832)] gyors terjeszkedése és tömeges fellépése Magyarországon [Rapid area expansion and mass occurrences of the invasive oak lace bug [Corythucha arcuata (Say, 1932)] in Hungary]. Erdészettudományi Közlemények, 2: 127-134.

CsóKa, G., HiRKa, A., 2017. Az inváziós tölgy csipkéspoloska (Corythucha arcuata) Magyarországon [Invasive oak lace bug (Corythucha arcuata) in Hungary]. Agrofórum: a Növényvédők és Növénytermesztők Havilapja, 28 (11): 30-34.

Csóka, G., Hirka, A., Mutun, S., Glavendeki, M., Mikó, Á., Szőcs, L., Paulin, M., Eötvös, C.B., GásPÁr, Cs., Csepelényi, M., SzÉnÁsi, Á., Franjevic, M., GninenKo, Y., DautbašIC, M., MuZejinovic, O., ZúBRiK, M., Netoiu, C., Buzatu, A., Balacenoiu, F., Jurc, M., Jurc, D., Bernardinelli, I., Streito, J.C., Avtzis, D., Hrašovec, B., 2020. Spread and potential host range of the invasive oak lace bug [Corythucha arcuata (Say, 1832) - Heteroptera: Tingidae] in Eurasia. Agricultural and Forest Entomology, 22: 61-74.

Csóka, G., Hirka, A., SomLYAI, M., 2013. A tölgy csipkéspoloska (Corythucha arcuata Say, 1832 - Hemiptera, Tingidae) első észlelése Magyarországon [First record of oak lace bug (Corythuca arcuata Say, 1832 - Hemiptera, Tingidae) in Hungary]. Növényvédelem, 49 (7): 293-296.

David'yan, G.E., Neymorovets, V.V., 2004. Stephanitis piri Fabricius - pear lace bug, Russia. [online]. In Interactive agricultural ecological atlas of Russia and neighboring countries. Ecomomic plants, pests and weeds. [cit. 2020-
04-13]. http://www.agroatlas.ru/en/content/pests/Stephanitis_pyri/index.html

Dobreva, M., Simov, N., Georgiev, G., Mirchev, P., GeorGIEVA, M., 2013. First record of Corythucha arcuata (Say) (Heteroptera: Tingidae) on the Balkan Peninsula. Acta Zoologica Bulgarica, 65 (3): 409-412.

Don, I., Don, C.D., Sasu, L.R., Vidrean, D., Brad, M.L., 2016. Insect pests on the trees and shrubs from the Macea Botanical Garden. Studia Universitatis „Vasile Goldis” Arad, 11 (2): 23-28.

Drake, C.J., Ruhoff, F.A., 1965. Lacebugs of the world: a catalog (Hemiptera: Tingidae). Bulletin of the United States National Museum, 234: 1-634.

Golub, V.B., Soboleva, V.A., 2018. Morfologicheskie razlichiya mezhdu Stephanitis pyri, Corythucha arcuata i C. ciliata (Heteroptera: Tingidae), rasprostranennymi ma yuge evropeiskoi chasti Rossii [Morphological differences between Stephanitis pyri, Corythucha arcuata and C. ciliata (Heteroptera: Tingidae) distributed in the south of the European part of Russia]. Zoosystematica Rossica, 27 (1): 142-145.

Hrašovec, B., Posarić, D., Lukić, I., Pernek, M., 2013. Prvi nalaz hrastove mrežaste stjenice (Corythucha arcuata) u Hrvatskoj [First record of Corythucha arcuata in Croatia]. Šumarski List, 9-10: 499-503.

KuCukbasmaci, I., 2014. Two new invasive species recorded in Kastamonu (Turkey): oak lace bug [Corythucha arcuata (Say, 1832)] and sycamore lace bug [Corythucha ciliata (Say, 1832)] (Heteroptera: Tingidae). Journal of Entomology and Nematology, 6 (8): 104-111.

MurraY, T., 2008. Corythucha arcuata Groton, Ma. [online]. [cit. 2020-04-13]. https://www.pbase.com/tmurray74/ image/102813489

Mutun, S., 2003. First report of the oak lace bug, Corythucha arcuata (Say, 1832) (Heteroptera: Tingidae) from Bolu, Turkey. Israel Journal of Zoology, 49: 323-324

Pest and Diseases Image Library, 2007. Sycamore lace bug (Corytuchaciliata)(Say).[online]. [cit.2020-04-13].https:// www.insectimages.org/browse/detail.cfm?imgnum $=5312026$

Rabitsch, W., 2008. Alien true bugs of Europe (Insecta: Hemiptera: Heteroptera). Zootaxa, 1827: 1- 44.

Simov, N., Grozeva S., Langourov, M., Georgieva, M, Mirchev, P., Georgiev, G., 2018. Rapid expansion of the oak lace bug Corythucha arcuata (Say, 1832) (Hemiptera: Tingidae) in Bulgaria. Historia Naturalis Bulgarica, 27: 51-55.

Zubrik, M., GubKa, A., Rell, S., Kunca, A., Valula, J., Galko, J., Nikolov, C., Leontovyc, R., 2019. First record of Corythucha arcuata in Slovakia. Plant Protection Science, 55: 129-133.

Received April 30, 2020

Accepted August 11, 2020 